\title{
Seasonal analysis of certain biochemical parameters of carps cultured in domestic sewage oxidation ponds
}

\author{
Sharique A. Ali ${ }^{1 *}$, M. Hanumanth Raju ${ }^{2}$, Naima Parveen ${ }^{1}$ \\ ${ }^{1}$ P.G. Department of Biotechnology and Zoology, Saifia College of Science, Bhopal, MP, India. \\ ${ }^{2}$ Department of Zoology, Government College for Women (Autonomous), Affiliated to Acharya Nagarjuna University, Guntur, Andhra Pradesh, India.
}

\begin{tabular}{l}
\hline ARTICLE INFO \\
\hline Article history: \\
Received on: March 03, 2021 \\
Accepted on: May 28, 2021 \\
Available online: September 01, 2021
\end{tabular}

Key words:

Fish culture, biochemical, serum

lactate, cholesterol, sewage

oxidation ponds

\begin{abstract}
Aquaculture from domestic sewage water is an alternate solution for growing scarcity of food to the pressures of population by producing fish and prawn using treated domestic waste effluents. It is an economically viable process particularly in the developing countries, including West Bengal, India. Keeping in view of the above viability, we have cultured three species of fishes Cyprinus carpio, Labeo rohita, and Cirrhinus mrigala in domestic sewage oxidation ponds designed as per National Environmental Engineering Research Institute, India. Biochemical parameters such as serum lactate and serum cholesterol have been investigated in the present study to determine the quality of fishes cultured in sewage oxidation ponds for human consumption. Among all experimental fishes, $C$. carpio exhibited higher serum lactate $(360.40 \mu \mathrm{g} / \mathrm{ml})$ as compared to $L$. rohita $(301.43 \mu \mathrm{g} / \mathrm{ml})$ and C. mrigala $(286.73 \mu \mathrm{g} / \mathrm{ml})$. Similarly, high serum cholesterol values were observed in C. carpio as compared to other two species in all the three seasons. During the monsoon season, maximum serum cholesterol were observed in sewage cultured C. carpio $(430.45 \mathrm{mg} / 100 \mathrm{ml})$ and minimum $(278.40$ $\mathrm{mg} / \mathrm{ml})$ in summer season followed by L. rohita $(248.25$ and $198.21 \mathrm{mg} / 100 \mathrm{ml})$ and C. mrigala $(278.40$ and $238.37 \mathrm{mg} / 100 \mathrm{ml}$ ). The fishes cultured in fresh water control ponds showed comparatively low values of serum lactate and cholesterol than the experimental fishes. Our results support the concept that good survival and adjustment of the fishes to the pre-treated nutritive domestic sewage water leads to their significant growth with an increased biochemical profile especially with higher levels of cholesterol, which are season dependent.
\end{abstract}

\section{INTRODUCTION}

Domestic sewage water fish culture is one of the best solutions for the scarcity of food and water for the growing population. The treated waste water can be used for landscape irrigation, agriculture, and production of fish and prawn for human consumption. The concept of sewage oxidation ponds has been found to be a good alternative for fish growth, which is a low cost and sustainable method for domestic waste treatment as well. The organic matter and other nutrients get reduced by algae and bacteria in the presence of sun light and in turn they become food for fish in the sewage oxidation ponds [1-8].

Fishes and their biochemical parameters can be considered as bio-indicators or bio-monitors of aquatic system for assessing

\footnotetext{
*Corresponding Author

Sharique A. Ali, P.G. Department of Biotechnology and Zoology,

Saifia College of Science, Bhopal, MP, India-462001.

E-mail:drshariqueali@yahoo.co.in
}

the quality of water and also the survival and growth rates of fishes grown in such environments [8-15]. Bio-chemical and pathological changes of fishes exposed to varying degrees and types of environmental pollution or stress have been measured by several investigators since last many years [9,16-20]. But little work has been done on the biochemical assessment of fishes grown in domestic sewage oxidation ponds to determine the quality of fish for human consumption. In this context, the serum lactate and cholesterol levels were studied in carps, Cyprinus carpio, Labeo rohita, and Cyprinus mrigla cultured in domestic sewage ponds for a period of 1 year.

\section{MATERIALS AND METHODS}

The experimental work was carried out in Shahpura Sewage oxidation ponds located at T.T. Nagar, $10 \mathrm{~km}$ south-east of Bhopal city $\left(25^{\circ}-17^{\prime}\right)$. There were eight sewage oxidation ponds constructed in two series of primary and secondary as per specifications of National Environmental Engineering Research Institute, Nagpur. Each pond had an area of 0.4 hectares. The 
ponds were typical sewage oxidation ponds, designated to treat biologically three million gallons of domestic sewage per day. Sewage from adjacent area was collected in a sump near Habibganj Railway Station, from where it was pumped to the oxidation ponds and detained for a period of 15-20 days for rapid microbiological transformation using sunlight. The raw sewage enters the primary pond through three inlets and after the specified detention period, the biologically treated effluent goes out from secondary pond through the outlet. The oxidation ponds are best choice for sewage purification where natural sunlight, tropical conditions, and biological oxidation takes place to reduce the excessive nutrients present in these ponds. In the present study, out of eight ponds as mentioned above, four were selected for fish culture. Two being primary, designated as IA and IIIA and two as secondary termed as IB and IIIB. The primary ponds receive untreated sewage and the secondary ponds receive treated sewage loads.

\subsection{Analysis of Serum Lactate and Serum Cholesterol}

Live, mature, and healthy C. carpio, L. rohita, and Cirrhinus mrigala weighing 1,200 $\pm 50 \mathrm{~g}$ were caught from sewage oxidation ponds and immediately brought for analysis. After 1-2 hours of laboratory acclimatization, they were used for biochemical analysis. By severing, caudal peduncle blood was collected in the pre oven sterilized centrifuge tubes and subjected to centrifugation for a period of 5 minutes at 3,000 rpm. The centrifuge tubes were stored at $4^{\circ} \mathrm{C}$ for serum precipitation. All the experiments were repeated 3-4 times and the data were statistically analyzed using standard methods $[21,22]$. Serum lactate was estimated following the procedure of Barker and Summerson [23] and Huckbee [24] as cited in Hawk's Physiological Chemistry [25]. Serum lactate values were expressed as $\mu \mathrm{g}$ per 1 $\mathrm{ml}$ of serum. Serum cholesterol was estimated colorimetrically by the method of Sacketh as described in "Microanalysis in Medical Biochemistry" by King and Wotton [26]. Serum cholesterol values are expressed in milligram per $100 \mathrm{ml}$ of serum.

\section{RESULTS AND DISCUSSION}

Serum lactate of carp fishes C. carpio, L. rohita, and C. mrigala cultured in the sewage oxidation ponds was analyzed at every 3 -month period for a year and compared with the values obtained from control fishes grown in a fresh water control pond of same dimension where the fishes were fed with normal diet. The values are expressed in $\mu \mathrm{g} / \mathrm{ml}$ (Fig. 1). All the values are mean of 3-4 replicates. Cyprinus carpio cultured in sewage ponds exhibited higher values at 3-month period $(140.37 \mu \mathrm{g} / \mathrm{ml})$ at 6-month period $(218.48 \mu \mathrm{g} / \mathrm{ml})$, at 9-month period $(290.13 \mu \mathrm{g} / \mathrm{ml})$ and $360.40 \mu \mathrm{g} / \mathrm{ml}$ at the end of the experiment, i.e., 12-month period. Cyprinus carpio from normal control pond exhibited 125.90, $164.30,201.36$, and $270.71 \mu \mathrm{g} / \mathrm{ml}$ at the period of 3, 6, 9, and 12 months, respectively. Thus, the experimental C. carpio recorded high lactate as compared to its control counterpart (Fig. 1). Labeo rohita and C. mrigala of experimental ponds recorded 131.50 and $129.00 \mu \mathrm{g} / \mathrm{ml}$ serum lactate at the time of 3-month period and showed higher serum values of 301.43 and $286.73 \mu \mathrm{g} / \mathrm{ml}$ at the end of the experiment, i.e., at 12-month period. Thus, serum lactate values of all three carp fishes cultured in oxidation ponds exhibited higher values in comparison to the control cultured fishes. It was noted that $C$. carpio recorded higher values of lactate as compared to other two experimental fishes, i.e., L. rohita and C. mrigala, probably because its mainly a polyphagous feeder and was perhaps more suited to adjust to the sewage - excessive nutrient environment (Fig. 1).

Serum cholesterol was estimated seasonally, (i.e., winter, summer, and monsoon) for a period of 1 year in all the carps: C. carpio, L. rohita, and C. mrigala cultured in sewage oxidation ponds and the values were compared with the same fishes cultured in normal fresh water control waters (Fig. 2). It was observed that high serum cholesterol was recorded in the monsoon season in C. carpio, L. rohita, and C. mrigala cultured in sewage oxidation ponds (Fig. 2) and minimum values in

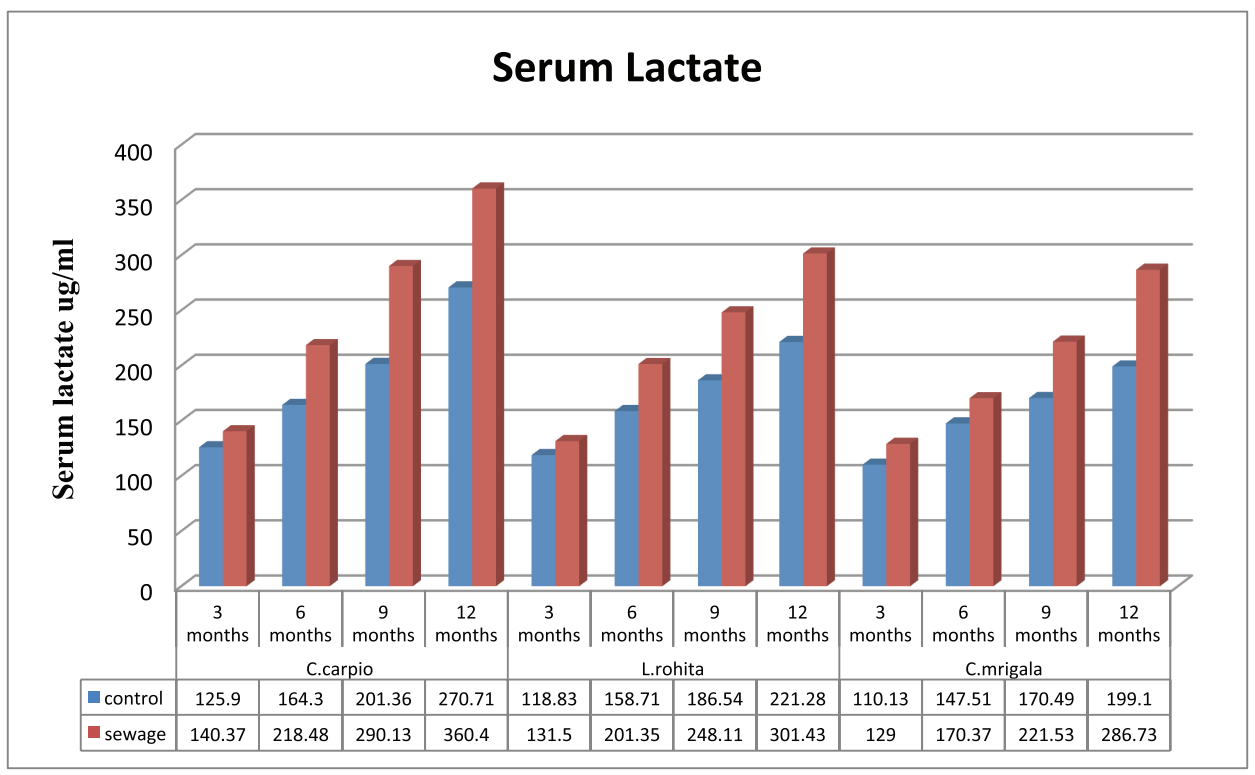

Figure 1: Serum lactate values of carps (C. carpio, L. rohita, and C. mrigala) cultured in control and sewage oxidation ponds. 


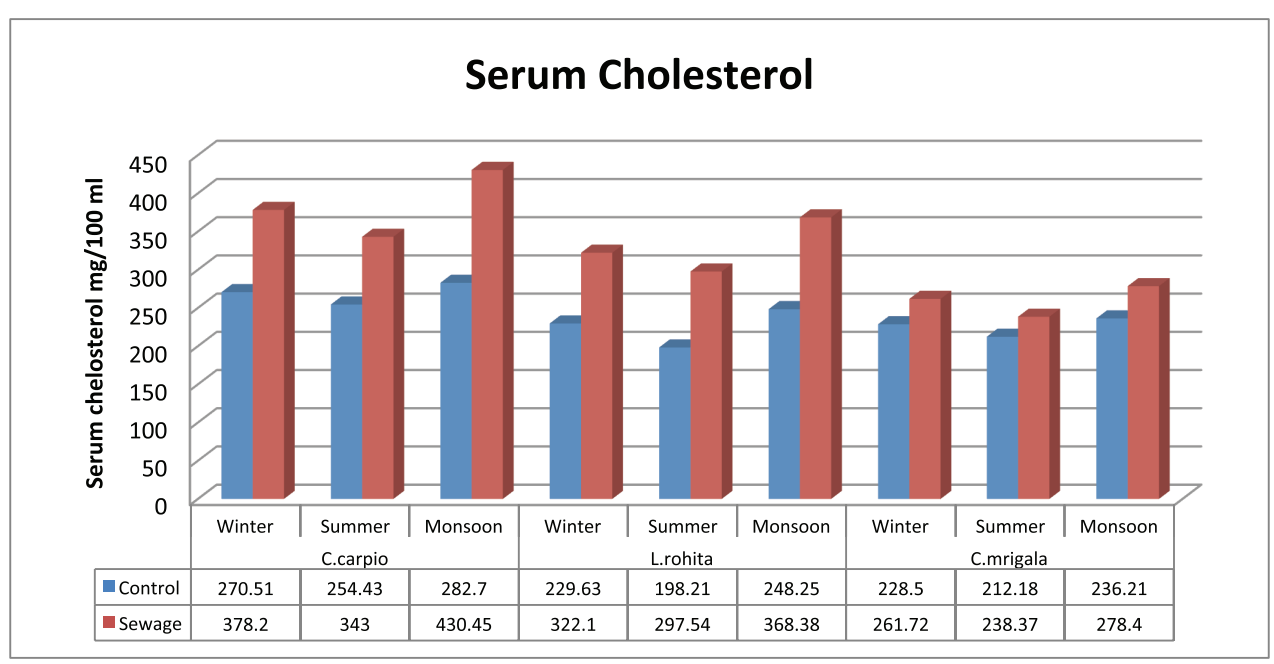

Figure 2: Serum cholesterol values of carps cultured in control and sewage oxidation ponds in three seasons (winter, summer and monsoon) for a period of 1 year.

summer season. Cirrhinus mrigala from sewage ponds exhibited $378.20 \mathrm{mg} / 100 \mathrm{ml}$ cholesterol values in winter, $343 \mathrm{mg} / 100 \mathrm{ml}$ in summer, and high $430.45 \mathrm{mg} / 100 \mathrm{ml}$ cholesterol in monsoon period. The control C. carpio recorded 270.51, 254.43, and $282.70 \mathrm{mg} / 100 \mathrm{ml}$ cholesterol values, respectively, in winter, summer monsoon seasons which are quite low as compared to the experimental fishes (Fig. 2). The other fishes L. rohita of sewage ponds exhibited 322.10, 297.54 and $368.38 \mathrm{mg} / 100 \mathrm{ml}$ and whereas C. mrigala exhibited 261.72, 238.37, and 278.40 $\mathrm{mg} / 100 \mathrm{ml}$ serum cholesterol values in winter, summer and monsoon seasons, respectively, which were found higher than their fresh water control cultured fishes (Fig. 2). Thus, C. carpio grown in sewage oxidation ponds exhibited higher cholesterol values in all seasons compared to other experimental fishes $L$. rohita and C. mrigala because this fish is a polyphagous feeder and it did not face any stress in the sewage oxidation ponds and also was able to maximally utilize the available total nutrients to show a healthy growth pattern.

In the present study, the fishes C. carpio, L. rohita, and C. mrigala cultured in domestic sewage oxidation ponds exhibited higher serum lactate values as compared to the fresh water cultured control fishes (Fig. 1). The reason for higher lactate values may be due to their increased feeding habits and related more physiological activities. Active swimmers have high glucose and lactate levels as compared to less active sluggish forms $[5,7,12,20$, $27,28]$. Another reason for high serum lactate levels may be due to large amounts of glycogen present in the liver of the experimental fish is converted in to lactate $[7,15,29]$.

Serum cholesterol values were also observed high in C. carpio, $L$. rohita, and C. mrigala (Fig. 2) as compared to the control ones. All the fishes recorded high serum cholesterol values in monsoon and minimum in summer seasons. Cholesterol plays an important part in body metabolism and a unique role in maturation of sexual organs spawning eggs and deposition of fats. Some work has been done on serum cholesterol in carps and other fishes on short term exposure to toxicants, heavy metals and to the starvation conditions. They observed slight alterations in hematological and biochemical experiments $[8,14,19,30-34]$. However, little attempt has been made on the assessment of biochemical parameters of fishes grown in sewage ponds, and hence the present work is first report of its kind.

The reason for higher values of serum cholesterol in monsoon season is due to their active metabolic activities and high rate of feeding to recover their normal values after spawning. Low serum cholesterol values of these fishes in summer are probably due to high temperature and peak ripeness of the gonads in both the sexes. In this period (summer), the fishes consume less amount of food and use the deposited fat in their tissues for the development of gonads. Earlier workers have also reported similar findings [14,35-39]. The higher values of serum lactate and cholesterol in the fishes are not due to any kind of toxicological, physiological stress or any other reason. The physiochemical characters, high nutrient environment and disease-free surroundings were the important conditions to the survival and growth rates of the fishes grown in sewage ponds $[1,3,5,15,40-42]$.

\section{CONCLUSION}

The present study shows that the major carps were best adjusted to the domestic sewage oxidation pond environments as they are herbivorous and utilized the excessive nutrients and organic matter present in the ponds. The serum lactate and cholesterol assessment of the fishes in the present study reveals that there is no negative impact on the fishes survival and growth in the domestic sewage secondary and tertiary oxidation ponds. However, more studies have to be done on biochemical assessment of sewage-oxidationpond grown fishes for human consumption point of view.

\section{ACKNOWLEDGMENTS}

The authors acknowledge the financial help provided by the U.S. Department of Agriculture (PL-480) Research Project in AES/208, FG In 628 to conduct this work.

\section{CONFLICTS OF INTEREST}

The authors report no financial or any other conflicts of interest in this work. 

oxidation ponds $2021 ; 9(05): 148-151$

\section{ETHICAL APPROVALS}

Not applicable.

\section{REFERENCES}

1. Modak NV. Sewage disposal. Bombay Municipal Corporation, Mumbai, India, 1938.

2. Vollenweider RA. Scientific fundamentals of the eutrophication of lakes and flowing water with special reference to nitrogen and phosphorus as factors in eutrophication. OECD, Paris, France, pp 14, 1968.

3. Akolkar AB. Biochemical and pathological studies of sewage cultured fishes. Ph.D. Thesis, Bhopal University, Bhopal, India, 1983.

4. Biswas AK, Arar A. Treatment and reuse of waste water. Butterworths \& FAO, London, UK, 1988.

5. Ali SA, Balkema A.A. Monitoring and evaluation of domestic waste water for fish culture. In: Aquaculture Research Needs for 2000 AD Oxford Univ. Press, Delhi, India, pp 355-66, 1992.

6. Drechsel P, Scott CA, Raschid-Sally L, Redwood M, Bahri A Wastewater irrigation and health. Routledge, London, UK, 2009.

7. Ching YC, Redzwan G. Biological treatment of fish processing saline waste water for reuse as liquid fertilizer. Sustainability 2017;9:1062.

8. Grabicová K, Grabic R, Fedorova G, Staňová AV, Bláha M, Randák $\mathrm{T}$, et al. Water reuse and aquaculture: pharmaceutical bioaccumulation by fish during tertiary treatment in a wastewater stabilization pond. Environ Pollut 2020;267:115593.

9. Abegg R. Some effects of inorganic salts on the blood specific gravity and tissue fluids of the blue gill, Lepomis macrochirus (Raf.). Physiol Zool 1950;23:124-34.

10. Burton DT, Zones AH, Cairns J. The effect of sublethal concentration of copper and zinc toxicity on fresh water fishes. Am Fisheries Soc Symp 1972;4:799-802.

11. Thirumavalavan R, Ganesan J. Comparative studies on lipid in fresh water and treated sewage water culture fish Labeo rohita. Int J Dev Res 2013;3(8):61-3.

12. Abdelhamid AM, Mehrim AI, Abdel Hamid AAM, El-Katan ME. Influence of feeding fish the dried-treated sewage on physiological responses and histological structure of the liver. Asian J Anim Vet Adv 2015;10(7):295-310.

13. Authman MMN, Zaki MS, Khallaf EA, Abbas HH. Use of fish as bioindicator of the effects of heavy metals pollution. J Aquac Res Dev 2015;6(4):328.

14. Singh S, Dixit PK, Patra AK. Biochemical analysis of lipids and proteins in three freshwater teleosts (Clarias batrachus, Channa punctatus, Anabas testudineus). Res J Recent Sci 2016;5(6):24-33.

15. Ali SA, Parveen N, Raju MH. On the analysis of certain biochemical parameters of carps cultured in domestic sewage oxidation ponds. Biosci Biotechnol Res Commun 2020;13(4):2311-8.

16. Shaffi SA. Biochemical compartmentation of fish tissues. Brain energy reserve and metabolic products. Acta Physiol Hung 1978;38:87.

17. Shaffi SA. Lead toxicity: biochemical and physiological imbalance in nine fresh water teleosts. Toxicol Lett 1979;4:155-61.

18. Shaikila IB, Tangavel P, Ramaswamy M. Adaptive trends in tissue acid and alkaline phosphatases of Sarotherodon mossambicus (Peters) under Sevin toxicity. Indian J Environ Health 1993;35(1):36-9.

19. Peyghan R, Takamy GA. Histopathological, serum enzyme, cholesterol and urea changes in experimental acute toxicity of ammonia in common carp Cyprinus carpio and use of natural zeolite for prevention. Aquac Int 2002;10:317-25.

20. Javed M, Usmani N. Stress response of biomolecules (carbohydrate, protein and liquid profiles) in fish Channa punctatus in habiting river polluted by Thermal Power plant effluent. Saudi J Biol Sci 2015;22(2):237-42.

21. Fisher RA. Statistical methods for research workers. 11th edition, Oliver and Boyd, London, UK, 1950.
22. Plummer DT. An introduction to practical biochemistry. 3rd edition, McGraw-Hill, London, UK, 1978.

23. Barker SB, Summerson W. The colorimetric determination of lactic acid in biological material. J Biological Chemistry. 1941; 138: 535-554.

24. Huckbee WE. Abnormal resting blood lactate. Am J Med 1961;30:833-9.

25. Bernald LO. Hawk's physiological chemistry. 14th edition, M.C. Graw - Hill Book Co, New York, NY, 1965.

26. King EJ, Wotton IDP. Micro analysis in medical biochemistry. 5th edition, Legmen Group Limited, London, UK, 1951.

27. Saravanan TS, Mohamed MA, Chandrasekar R, Sundramoorthy M. Fresh water fishes as indicators of Kaveri River pollution. J Environ Biol 2003;24(4):381-9.

28. Bhoi SS, Patole SS. Biochemical alternation in freshwater fish, Channa marulius (Ham Buch) exposed to 1/4th sublethal concentrations of cypermethrin and fenvalerate. Int J Recent Sci Res, 2019; 10(10):35236-9.

29. Raju MH. Studies on certain tissue enzymes of sewage cultured fishes with special reference to biochemical and pathological assessment for human consumption. A thesis for the degree of Doctor of Philosophy in Zoology under the faculty of Life Sciences, Barkatullah University, Bhopal, India, 1994.

30. Barnes H, Blackstock ZJ. Estimation of lipids in marine animals and tissue. Detailed investigation of the phosphovanilin method for total lipids. J Exp Mar Biol Ecol 1973;12:307-16.

31. Zuraini A, Somchit MH, Goh Y, Arifah AK. Fatty acid and amino acid composition of three local Malaysian Channa punctatus fish. Food Chem 2006;97(4):674-8

32. Katti SR, Sathyanesan AG. Lead nitrate induced changes in lipid and cholesterol levels in the freshwater fish Clarias batrachus. Toxicol Lett 1983;19:93-6.

33. Henderson RJ, Tocher DR. The lipid composition and biochemistry of freshwater fish. Prog Lipid Res 1987;26:281-347.

34. Hoseini SM, Ghelichpour M. Effects of pre-sampling fasting on serum characteristics of common crap (Cyprinus carpio L.). Int J Aquatic Biol 2013;1(1):6-13.

35. Siddiqui MA. Seasonal variations in total cholesterol content in different tissues of Ophiocephalus punctatus. Indian J Exp Biol $1966 ; 4: 122-3$

36. Yilmaz B, Konar V, Kutlu S, Sandal S, Canpolat S, Gezen MR, Kelestimur H. Influence of chronic morphine exposure on serum LH, FSH, testosterone levels, body and testicular weights in the developing male rat. Arch Androl 1999;23(3):319-31.

37. Gill HS, Weatherly AH. Protein, lipid and calorie contain of blunt nose minnow, Notatus rafinosque, during growth at different temperatures. J Fish Biol 1984;25:491-500.

38. Dutta H, Das AB, Farkas T. Role of environmental temperature in seasonal changes in fatty acid composition of hepatic lipid in air breathing Indian Teleost, Channa punctatus (Bloch). Comp Biochem Physiol B 1985;81(B):341-7.

39. Vass KF. Notes on the freshwater fish culture in domestic sewage in the tropics. Landbouw, Batavia, NY, vol. 20, pp 331-48, 1948.

40. Bhatia HL, Sastry CA. Rearing of fish fry of Indian major carps in sewage stabilisation ponds. In: Cotton A, Pickford J (eds.). Water and waste engineering in Asia: proceedings of the 8th WEDC International Conference, Madras, India, 1982, pp 79-82.

41. Bunting SW, Kundu N, Mukherjee M. Renewable natural resource-use in livelihoods at the Calcutta peri-urban interface: literature review. DFID, London, UK, p 37, 2001.

42. Datta S. PGDIF class note on sewage-fed aquaculture. 2007. http:// courseware.cutm.ac.in uploads

\section{How to cite this article:}

Ali SA, Raju H, Parveen N. Seasonal analysis of certain biochemical parameters of carps cultured in domestic sewage oxidation ponds. J Appl Biol Biotech 2021; 9(05):148-151. 